\title{
Using Rubrics in a CAPstone EngineERING Design Course
}

\author{
Richard G. Zytner ${ }^{1}$, John Donald ${ }^{1}$, Karen Gordon ${ }^{1}$, Ryan Clemmer ${ }^{1}$ and Jason Thompson ${ }^{2}$ \\ ${ }^{1}$ School of Engineering and ${ }^{2}$ Open Learning, University of Guelph \\ *rzytner@uoguelph.ca
}

\begin{abstract}
Rubrics have been developed to assess the proposal, interim report, final report and proposal as related to the engineering capstone project, to better assess the performance of the students and provide feedback to the students. The presentation will outline how the rubrics were developed and highlight some the challenges that arose in implementing them. In addition, the rubrics were structured to address the majority of graduate attributes outlined by the Canadian Engineering Accreditation Board (CEAB). As such the rubrics assess student performance in the following graduate attributes: design, problem analysis, investigation, communication skills, impact of engineering on society and environment, and economics and project management. Through the learning management system used at the SOE, the rubric data can also be collected and reviewed as part of the graduate attribute process that has become an important component of the CEAB accreditation process. Challenges in using the learning management system will also be discussed.
\end{abstract}

Keywords: capstone design course, rubrics, graduate attributes, learning management system.

\section{INTRODUCTION}

A capstone engineering design course is an important component of an undergraduate engineering degree as it allows the students to apply their previously acquired knowledge to a problem specific to their program of study. These projects are open-ended and result in a comprehensive design report. For many engineering schools in Canada, these design projects are program specific and are graded by faculty working in that specific program. In theory this should provide for a consistent marking scheme, but that does not always happen as each faculty member has a different perspective on what an ideal project report short look like. The marking of capstone reports is further complicated in programs like the School of Engineering (SOE), University of Guelph, where multi-disciplinary groups are allowed. Therefore to provide some consistency to the grading and improve feedback to the students, various rubrics have been developed in the SOE.

Challenges with using rubrics have been noted in the literature including the improper assessment of expectations [1], the inability to effectively evaluate critical thinking [2] and difficulty relating assessment to performance in class [3]. With Graduate Attributes (GA) becoming a requirement in attaining and maintaining accreditation by Canadian Engineering Accreditation Board [4], the SOE decided to develop GA-based rubrics for capstone design projects to collect GA data to track and assess student performance and support its curriculum improvement process.

Initially a rubric was developed to collect GA data and evaluate student performance in the final design report. The graduate attributes tracked were design, problem analysis, investigation, communication skills, impact of engineering on society and environment, and economics and project management. The rubric was hosted on CourseLink, the learning management system (LMS) used by the University of Guelph. CourseLink is powered by Desire2Learn's (D2L) Brightspace [5]. Subsequently, rubrics were added for the proposal, interim report and poster.

The paper will detail the rubrics that were developed for engineering capstone course offered in the SOE, the challenges faced in using it for seven engineering programs, some that are very distinct, and the positives and negatives of hosting the rubric on a (LMS.

\section{BACKGROUND}

\subsection{Design Sequence}

The SOE offers seven accredited engineering programs: Biological Engineering, Biomedical Engineering, Engineering Systems and Computing, Computer Engineering, Environmental Engineering, Mechanical Engineering and Water Resources Engineering. All students in these seven programs take the common core design sequence that consists of four courses: ENGG*1100 Engineering and Design I, ENGG*2100 Engineering and Design II, ENGG*3100 
Engineering Design III and ENGG*41x0 (x represents the seven programs) Engineering Design IV.

The design course sequence integrates mathematics, science, engineering science and complementary studies as each student develops maturity and moves through the program. New design tools are continually introduced along with information on safety, reliability, codes and standards, economic considerations and environmental concerns.

The overall objective of the design sequence is to introduce students to all aspects of the design process including problem identification, analysis, synthesis, communication and reporting. Team design problems are general, with multi-disciplinary projects in ENGG*1100 and ENGG*2100. In ENGG*3100, student teams work on open ended substantial engineering problems pertaining to their specific program. For ENGG*41x0, students identify a capstone design project that is team based. Each student is required to work on a project related to their program of study, with multi-disciplinary teams encouraged but not required.

\subsection{Capstone Design Course}

The capstone design course, Engineering Design IV is taken in the final semester of studies, allowing the students to apply the previously learned engineering science and design content to a relevant design problem. Students work in teams of 3 to 5 and are encouraged to develop projects with students in other disciplines. The majority of the design problems come from an industrial setting, through contacts from instructors or advisors, and from the students themselves while on coop placements. The final project is presented via a poster during the SOE design day.

The objective of Engineering Design IV is to give students the experience of developing solutions to the types of open-ended, multi-faceted problems that are typical of real engineering situations. It is intended to provide a bridge between the formal learning environment of the university and the demanding world of professional practice. The design project must involve the application of engineering principles and computers for the design of elements, systems and processes to provide a solution for a specified problem in the program of specialization.

To achieve the objective stated above, the student teams are required to submit a proposal, interim project report, final design report, submit project memos and prepare a poster. Each team is advised by a faculty member who must hold a P.Eng. license.

For the proposal, the students articulate a problem that is defined, analysed and described with regard to physical, sociological, political, environmental, and economic characteristics. The material in the proposal defines the scope, duration, schedule and deliverables for the interim and final design reports.

An interim report is prepared at the midpoint of the semester and submitted for evaluation. The interim report details the progress of the project, including design alternatives.

The final design report describes the developed design solution and addresses the deliverables agreed to at the proposal stage. The faculty advisor evaluates the work submitted and assigns a grade to it.

In addition to the proposal and reports, students prepare technical memos that provide an overview of the project and summarize all milestones to the course coordinator.

Completion of the project requires the presentation of a poster. Faculty, staff, local engineers, fellow students and the public are invited to view the posters, discuss them with the participants. The posters and the ability to answer questions are graded by teams of external examiners, who all required to hold a P.Eng. designation.

\subsection{Learning Management System}

The University of Guelph uses CourseLink (D2L's Brightspace) as the LMS [5]. CourseLink provides many features for instructors, including hosting of course content, storing student grades, storing student work in the "Dropbox" feature, and facilitating the marking of student work via Dropbox with or without rubrics. Additionally, CourseLink allows assessments to be completed electronically and compiled for future review and analysis.

\section{DEVELOPMENT OF RUBRICS}

The SOE course mapping process identified that Engineering Design IV directly applied 8 of the 12 CEAB graduate attributes (GAs) at the mastery level, the level expected of a graduating student. These GAs are applied directly to the design project, irrespective of whether the capstone project was a preliminary design, final design or construction of a prototype. The applicable GAs are:

2.0 Problem Analysis

3.0 Investigation

4.0 Design

5.0 Engineering Tools

6.0 Individual \& Team Work

7.0 Communication

9.0 Impact of Engineering on Society and Environment

11.0 Economics and Project Management

The SOE developed a framework of 41 subordinate high level indicators (criteria) that map directly to the 12 
CEAB graduate attributes. The number of criteria varies in each GA category as seen by the Proposal Rubric in Appendix A and are numbered accordingly for tracking with the LMS (see column labelled SOE\# in A.1).

In total, four different rubrics were developed, with each rubric having a different set of criteria comprising of four performance levels and corresponding outcome statements to provide guidance to students in completing the task, faculty in grading and most importantly providing feedback on the task. Rubrics were developed for the following components of the course, with the corresponding number of criteria:

$>$ Proposal (12 criteria)

$>$ Interim Report (14 criteria)

$>$ Final Project Report (33 criteria)

$>$ Poster Presentation (12 criteria)

Each criterion has outcome statements that correspond with the following 4-point scale:

$>$ Exceeds Expectations (4 pts) - 80 to $100 \%$

$>$ Adequately meets Expectations (3 pts) - 70 to $79 \%$

$>$ Minimally meets Expectations (2 pts) - 60 to $69 \%$

$>$ Fails to meet Expectations (1 pts) - less than $60 \%$

The value of $60 \%$ for the Fails to meet Expectations category was selected to coincide with the $60 \%$ minimum average allowed in the continuation of study for engineering at the University of Guelph.

\subsection{Differences Between Rubrics}

For the Proposal Rubric, Appendix A.1, the rubric criteria were selected to reflect the early stage of the project, with emphasis on problem statement, literature review, outlining constraints and identifying possible solutions in a very cursory sense, to show that the project team has an understanding of what is required to solve the problem. These criteria were then supported by a short overview on engineering tools required to complete the project, and then from a planning perspective, the resources that would be needed. Planning is an important part of the proposal, and as such project management techniques were included. Communication is an important component of any engineering report and so statements on organization, formatting and literacy were included. It should be noted that the communication criteria are the same for all three report rubrics.

The interim report is used as a check to see where the student groups are at the mid-way point of the project. Accordingly, some of the indicators were adjusted to determine the status of the project, with specific reference made to whether the team is following the timeline originally proposed in the proposal, and if behind, what is being done to get back on schedule. The other indicator statements are similar to the statements in the proposal, with the exception being that the students are expected to provide additional detail and clarity. For example, for the problem statement, the team should have clearly clarified the problem at the mid-way point of the project.

The Final Report Rubric has 33 comprehensive criteria. The rubric evaluates all aspects of the design project from investigation to design, regardless of whether a final design or the development of a prototype has been completed, and includes safety and impact on society. The number of criteria assessed in each graduate attribute varies to provide some weighting. For example the "design" portion of the final report has 12 criteria, while the "engineering tools" portion has only three. On a relative basis, this weight perspective makes sense as design is the focus of the report. This weighting structure continues for all other GA indicators.

The Final Report Rubric also has two GA indicators that are optional: "problem analysis" and "investigation". The optional category arose in response to feedback from faculty after the first application of the rubric. It was found that not all design projects had a significant "problem analysis" or "investigation" component. All projects have elements of these components, but not necessarily at a level that should be highly weighted in the rubric. In applying the Final Report Rubric, the student group and faculty advisor now decide if the project has significant elements of the "problem analysis" or "investigation" components and the final report is then graded accordingly.

The emphasis of the Poster Rubric is to assess communication skills, and accordingly was broken into three parts that corresponding to the SOE GA indicator statements. Subordinate 6.2: demonstrate leadership through team building, providing feedback and positive attitude to ensure that all group members participate in the poster presentation, Subordinate 7.1: develop and deliver clear key concepts using methods appropriate for intend audience, and Subordinate 7.2: critically evaluate received information. The rubric criteria for 6.2 include cohesiveness of team and individual contribution, 7.1 include problem statement, clarity, technical competence, technical content, discussion and conclusion, while 7.2 include appearance, literacy, dialogue and professionalism \& poise.

The application of the poster rubric is different from the other rubrics in that faculty members do not grade them. Instead the SOE relies mainly on professional engineers who do not have faculty appointments. These professional engineers come from businesses in the Guelph area, who are willing to give some of their time to grade the posters on design day. Some are alumni, but that is not a requirement. 


\subsection{Rubrics and LMS}

The students submit their work (proposal, two reports and poster) in electronic format to the CourseLink Dropbox. Through the LMS, each faculty advisor can access the submission for review and grading. Some faculty still prefer to grade a hard copy, so all groups are required to submit a hard copy to their advisor. To grade, the faculty opens the rubric through CourseLink, and for each rubric criteria, the most appropriate performance level with accompanying rubric outcome statement is selected to represent work submitted. That is, Level 4, Level 3, Level 2 and Level 1. Faculty also have the option of writing additional feedback and comments in the rubric. Some faculty also mark these comments directly on the hard copies of the reports.

Once marking is completed by faculty, the rubric results are automatically available to the students, along with the resulting grade. Making the rubric results available to the students is important as the students are able to quickly see from an outcomes assessment perspective, where improvement is needed. The grades are also immediately distributed to all members of the group via the CourseLink gradebook feature.

As noted earlier, the "problem analysis" and "investigation" components of the final report rubric are optional. If either of these indicators are not assessed by the faculty member (which would have been previously agreed to between the students and the faculty advisor), the faculty advisor must manually revise the rubric grade to account for the optional selection. This manual workaround is required, as CourseLink currently does not have the functionality to handle optional indicator statements.

For the Poster Rubric, hard copies are used by the judges. Technically, the Poster Rubric could be graded on-line with tablets or smart-phones, but this is not operationally feasible at this time. As such, the course coordinator arranges for the hard copy poster grades to be entered into CourseLink. This allows for the poster and corresponding assessment to be stored by the LMS for future access if needed.

An important feature of using the rubrics on the LMS system for GA data collection and assessment purposes is the ability to associate the rubric criteria to the graduate attributes and SOE GA indicators for each student. Each rubric criteria is linked to the relevant SOE indicator statement using the Competency tool in CourseLink. Once the rubric criteria is associated within the LMS, performance level data for the cohort can be extracted and presented in relation to the GA indicator framework in an efficient manner.

\section{RESULTS}

The rubrics have now been used in five offerings of Engineering Design IV. Overall, faculty and students have accepted the rubrics, and generally report that the rubrics are easy to use for writing the report, and for grading and reviewing feedback on the submitted work.

One improvement that has helped with the adoption of the rubric by faculty is the incorporation of the optional category for some of the indicators; currently in place for investigation and problem analysis. These optional categories make the rubric for the final design report more flexible to apply to design projects that are building a prototype, as many of these projects bypass the investigation and problem analysis phase at the start of the project. Some faculty have raised the concern that more of the indicators should be optional, but upon review, the SOE has decided to keep these indicators mandatory, as the remaining indicators in the rubrics are required elements in which a graduating engineering student must demonstrate competence.

One challenge common to developing and implementing any rubric is writing the appropriate outcome statements for each of the criteria performance levels. As this is version 3 of the rubrics, some refinement based on faculty and student use has already happened. It is expected that refinements will continue moving forward, but the SOE has decided to keep the rubrics consistent and in place for the next 2 years. Doing so will provide the GA-based student performance data for faculty for review as part of the SOE curriculum improvement process.

Some feedback from the faculty has suggested that the SOE reduce the total number of criterion in the rubric. This would reduce the amount of effort required to use the rubrics to grade the work. Unfortunately, reducing the number of criteria would also reduce the amount of data that would be available for review in the SOE curriculum improvement process. The trade-off with a lower number of criteria being assessed is coarser outcome data, which potentially makes it more difficult to identify potential improvements. The SOE plans to review the number of criterion after a 2-year period of data collection has passed as mentioned above.

One ongoing item of discussion is the use of the rubrics to simultaneously provide a student grade, as well as provide performance data for graduate attribute assessment. Some faculty feel that the rubric should only be used to determine the outcome competency of the graduating student, with the report being graded a second time with a different assessment tool to assign the actual grade. Other faculty feel that, on the practical side, it would be too onerous to mark the design report twice. The SOE has considered this point and decided to proceed by using the rubrics for both GA outcome 
assessment and grading. As such, the grade for each rubric performance level was set to match the University of Guelph grading levels as outlined in Section 3.0. The grade of $60 \%$ was selected for the Fails to meet Expectations level (Level 1), as students need to achieve a $60 \%$ average in order to graduate with a B.Eng. Degree according to the continuation of study regulations. The grades have been monitored, and the review suggests that the overall grade received by the student on the final report has increased slightly when using the GA-based rubrics. So far, this has not been flagged as a problem. Further study is warranted.

Informal discussion with the students suggests that students like both the direction and feedback provided by the rubrics. This is a positive development as increased feedback helps with understanding the positive and negative components of the submitted design work, which can only improve the final product. One challenging aspect is that it has been observed that some students are "writing" to the rubrics. These students feel that the indicator statements need to be specifically addressed in the report under separate sections that have the indicator statements as the head. In some cases it might be appropriate to have a separate section for a specific indicator, while in other cases, it would be best to just let the report flow where the indicators are adequately discussed in a paragraph or two as part of a related section.

\subsection{Functionality of LMS}

The use of the rubric and outcomes assessment functionality of the CourseLink LMS has gone relatively smoothly. The students are able to upload their files whether reports or posters effectively and efficiently. The faculty can access the student work and grade the work on-line. Some faculty grade a hard copy and then transcribe the comments onto the rubric page, while some grade the work directly on-line. For the on-line grading, currently it works best by having two browsers open; one with the report being graded and the other the rubric. Comments on the report are then entered directly into the rubric. Selecting the on-line grading option is more of an individual faculty comfort factor. One added bonus for the course coordinator is that the grades for each task is automatically added to the gradebook from all groups and individuals via the CourseLink gradebook feature.

Having the students submit the work to the CourseLink Dropbox also provides an efficient means for the SOE to store the work for review by CEAB visitors during site visits. This was tried during the last CEAB visit and the visitors had no issues accessing and reviewing the electronic information. They saw the reports and the corresponding feedback from the faculty advisor.
From GA data perspective, all rubric data is stored by the LMS which can be accessed for future analysis when reviewing student performance for each GA. Currently the download is done on a per course basis. However, the SOE with the aid of Open Learning at the University of Guelph, has requested from D2L that a more automated approach be developed.

\section{SUMMARY}

Overall the adopted rubrics have provided a process to improve feedback to the students for a variety of course activities; proposal, interim report, final report and poster. The feedback to the students has improved, but in doing so it has also provided valuable graduate outcome data, which is needed for the continuous feedback system. Having outcome data makes it possible to improve the engineering programs offered by the SOE. This data collection is possible through the CourseLink LMS system provided by D2L. Some improvements are needed like optional indicator statements and the ability to locally ask for data downloads so that the GA data can be reviewed.

\section{Acknowledgements}

The authors acknowledge the efforts of all the faculty in the School of Engineering, especially that of Dr. Warren Stiver, P.Eng. in developing the various graduate attribute indicators and associated outcome statements that provided the foundation of the rubrics presented in this paper. The comments provided during the initial implementation phase of the rubrics are also appreciated as they helped refine the rubrics.

\section{References}

[1] William Bishop, Oscar Nespoli and Wayne Parker (2012) "Rubrics for Accreditation and Outcomes Assessment in Engineering Capstone Projects", Proc. Canadian Engineering Education Association (CEEA12) Conf., Winnipeg, MB, June 17-20, 7pp.

[2] Patricia Ralston and Cathy Bays (2010) "Refining a Critical Thinking Rubric for Engineering " Proceedings of the 117th ASEE Annual Conference and Exhibition, Louisville, KY, AC 2010-1518, 16 pp.

[3] Kevin P. Saunders , Charles E. Glatz , Mary E. Huba, Maureen H. Griffin , Surya K. Mallapragada and Jacqueline V. (2003), "Using Rubrics to Facilitate 
Students’ Development of Problem Solving Skills", in Proc. American Society for Engineering Education Annual Conference, Nashville, Tennessee, June 2225, 16 pp.
[4] CEAB (2014) Accreditation Criteria and Procedures, http://www.engineerscanada.ca/accreditationresources, Jan 12, 2015.

[5] Desire2Learn (2015), Learning Management System. http://www.brightspace.com/, March 13.

\section{APPENDIX A: SAMPLE RUBRIC}

\section{A.1 Proposal Rubric}

\begin{tabular}{|c|c|c|c|c|c|c|}
\hline & & $\begin{array}{l}\text { Exceeds Expectations } \\
\text { Expectations } \\
\text { Points: } 4\end{array}$ & $\begin{array}{l}\text { Adequately meets } \\
\text { Expectations } \\
\text { Points: } 3\end{array}$ & $\begin{array}{l}\text { Minimally Meets } \\
\text { Expectations } \\
\text { Points: } 2\end{array}$ & $\begin{array}{l}\text { Fails to meet } \\
\text { Expectations } \\
\text { Points: } 1\end{array}$ & Score \\
\hline SOE\# & INDICATOR & \multicolumn{4}{|c|}{ STATEMENTS } & \\
\hline 4 & \multicolumn{6}{|c|}{$\begin{array}{l}\text { Design: An ability to design solutions for complex, open-ended engineering problems and to design systems, components or } \\
\text { processes that meet specified needs with appropriate attention to health and safety risks, applicable standards, and economic, } \\
\text { environmental, cultural and societal considerations. }\end{array}$} \\
\hline 4.2 & $\begin{array}{l}\text { Construct design-specific } \\
\text { problem statements }\end{array}$ & \begin{tabular}{|l|} 
Constructs complete \\
problem identification \\
with a thorough \\
discussion on the \\
expected design \\
components that is \\
consistent with the \\
readily available \\
information.
\end{tabular} & $\begin{array}{l}\text { Constructs complete } \\
\text { problem identification } \\
\text { with a light discussion } \\
\text { on the expected } \\
\text { design components } \\
\text { that is consistent with } \\
\text { readily available } \\
\text { information. }\end{array}$ & $\begin{array}{l}\text { Constructs } \\
\text { problem } \\
\text { identification with } \\
\text { no discussion and } \\
\text { does not consider } \\
\text { all available } \\
\text { information. }\end{array}$ & $\begin{array}{l}\text { Problem } \\
\text { identification not } \\
\text { consistent with } \\
\text { available } \\
\text { information. }\end{array}$ & \\
\hline 4.2 & $\begin{array}{l}\text { Construct design-specific } \\
\text { problem statements - } \\
\text { Literature Review }\end{array}$ & $\begin{array}{l}\text { Prepares an excellent } \\
\text { literature review } \\
\text { pertaining to the } \\
\text { problem }\end{array}$ & $\begin{array}{l}\text { Prepares a good } \\
\text { literature review } \\
\text { pertaining to the } \\
\text { problem }\end{array}$ & \begin{tabular}{|l} 
Prepares a fair \\
literature review \\
pertaining to the \\
problem
\end{tabular} & $\begin{array}{l}\text { No literature review } \\
\text { provided }\end{array}$ & \\
\hline 4.2 & $\begin{array}{l}\text { Construct design-specific } \\
\text { problem statements - } \\
\text { supported by } \\
\text { constraints, criteria and } \\
\text { assumptions }\end{array}$ & $\begin{array}{l}\text { Identifies and discusses } \\
\text { the all constraints, } \\
\text { criteria and } \\
\text { assumptions }\end{array}$ & \begin{tabular}{|l} 
Identifies and discusses \\
the major constraints, \\
criteria and \\
assumptions
\end{tabular} & $\begin{array}{l}\text { Identifies the } \\
\text { constraints, criteria } \\
\text { and assumptions }\end{array}$ & $\begin{array}{l}\text { Fails to identify } \\
\text { and constraints, } \\
\text { criteria and } \\
\text { assumptions }\end{array}$ & \\
\hline 4.2 & $\begin{array}{l}\text { Construct design-specific } \\
\text { problem statements - } \\
\text { supported from a social, } \\
\text { environmental and } \\
\text { economic, health and } \\
\text { safety perspective }\end{array}$ & $\begin{array}{l}\text { Anticipate and explain } \\
\text { needs and impacts in } \\
\text { social, environmental } \\
\text { and economic, health } \\
\text { and safety terms } \\
\text { beyond the immediate } \\
\text { client and users. }\end{array}$ & $\begin{array}{l}\text { Anticipate needs and } \\
\text { impacts in social, } \\
\text { environmental and } \\
\text { economic, health and } \\
\text { safety terms for client } \\
\text { and users. }\end{array}$ & $\begin{array}{l}\text { Explain the problem in } \\
\text { social, environmental, } \\
\text { economic, health and } \\
\text { safety terms }\end{array}$ & $\begin{array}{l}\text { Fails to consider the } \\
\text { problem in social, } \\
\text { environmental, } \\
\text { economic, health and } \\
\text { safety terms }\end{array}$ & \\
\hline 4.6 & $\begin{array}{l}\text { Implement } \\
\text { engineering design } \\
\text { solutions - Identifies } \\
\text { possible solutions } \\
\text { from a proposal } \\
\text { perspective. }\end{array}$ & \begin{tabular}{|l|} 
Discusses the possible \\
design approach, \\
identifying some \\
possible solutions and \\
recognizing available \\
resources.
\end{tabular} & $\begin{array}{l}\text { Discusses the possible } \\
\text { design approach, } \\
\text { identifying some } \\
\text { possible solutions but } \\
\text { does not recognize } \\
\text { available resources. }\end{array}$ & $\begin{array}{l}\text { Presents a possible } \\
\text { design approach and } \\
\text { does not recognize } \\
\text { available resources. }\end{array}$ & $\begin{array}{l}\text { No design } \\
\text { approach or } \\
\text { possible design } \\
\text { solution provided. }\end{array}$ & \\
\hline 5 & \multicolumn{5}{|l|}{ Engineering Tools } & \\
\hline
\end{tabular}




\begin{tabular}{|c|c|c|c|c|c|}
\hline 5.1 & $\begin{array}{l}\text { Select appropriate } \\
\text { engineering tools from } \\
\text { various alternatives - a } \\
\text { proposal perspective }\end{array}$ & \begin{tabular}{|l|l} 
Identify the hardware & Ic \\
tools (physical, hand \\
and prototyping) and \\
software tools that may \\
be used in the \\
development of the \\
design, with critical \\
discussion on how \\
these tools will benefit \\
the design.
\end{tabular} & \begin{tabular}{|l|l} 
Identify the hardware & Ic \\
tools (physical, hand & tc \\
and prototyping) and \\
software tools that \\
may be used in the
\end{tabular} & $\begin{array}{l}\text { Identify the hardware } \\
\text { tools (physical, hand } \\
\text { and prototyping) and } \\
\text { software tools that } \\
\text { may be used in the } \\
\text { development of the } \\
\text { design, with some } \\
\text { supporting } \\
\text { documentation. }\end{array}$ & $\begin{array}{l}\text { Only rudimentary tools } \\
\text { were identified for } \\
\text { possible use in the } \\
\text { design, with no } \\
\text { supporting } \\
\text { documentation. }\end{array}$ \\
\hline 7 & \multicolumn{5}{|c|}{$\begin{array}{l}\text { Communication Skills: An ability to communicate complex engineering concepts within the profession and with society } \\
\text { at large. Such ability includes reading, writing, speaking and listening, and the ability to comprehend and write effective } \\
\text { reports and design documentation, and to give and effectively respond to clear instructions. }\end{array}$} \\
\hline 7.1 & $\begin{array}{l}\text { Develop and deliver clear, } \\
\text { key concepts using } \\
\text { methods appropriate for } \\
\text { the intended audience - } \\
\text { supporting material, } \\
\text { including Letter of } \\
\text { Transmittal and Executive } \\
\text { Summary }\end{array}$ & \begin{tabular}{|l|} 
Clearly and concisely \\
indicates purposes of \\
report using professional \\
language appropriate for \\
target audience. Provides \\
context of deliverables. \\
Properly addressed and \\
signed.
\end{tabular} & $\begin{array}{l}\text { Clearly and concisely } \\
\text { indicates purpose of } \\
\text { report. Provides } \\
\text { context of overall } \\
\text { project. Properly } \\
\text { addressed and signed. }\end{array}$ & \begin{tabular}{|l} 
Purpose of report is \\
vague. Context of \\
deliverables as part of \\
project stated. \\
Properly addressed \\
and signed.
\end{tabular} & $\begin{array}{l}\text { Purpose of report not } \\
\text { clear or obvious. } \\
\text { Letter is bound within } \\
\text { report, and improperly } \\
\text { addressed or signed. }\end{array}$ \\
\hline 7.1 & $\begin{array}{l}\text { Develop and deliver clear, } \\
\text { key concepts using } \\
\text { methods appropriate for } \\
\text { the intended audience - } \\
\text { Organization of Report }\end{array}$ & $\begin{array}{l}\text { Objectives and scope of } \\
\text { project are clearly } \\
\text { provided in a complete, } \\
\text { thoughtful order. Key } \\
\text { report elements are } \\
\text { integrated and mutually } \\
\text { reinforcing. }\end{array}$ & $\begin{array}{l}\text { Objectives and scope } \\
\text { of project are clear. A } \\
\text { complete order with } \\
\text { evidence of logical } \\
\text { thinking. }\end{array}$ & $\begin{array}{l}\text { Aspects of problem } \\
\text { objectives or scope } \\
\text { unclear. Reasonable } \\
\text { presentation in all } \\
\text { sections, with some } \\
\text { thought and effort. }\end{array}$ & $\begin{array}{l}\text { Random order to } \\
\text { structure of report. } \\
\text { Little effort or } \\
\text { thought. }\end{array}$ \\
\hline 7.1 & \begin{tabular}{|l|} 
Develop and deliver clear, \\
key concepts using \\
methods appropriate for \\
the intended audience - \\
Figures \\
\& Formatting
\end{tabular} & $\begin{array}{l}\text { Clear, informative figures } \\
\text { with excellent } \\
\text { formatting. Enhance } \\
\text { presentation consistently } \\
\text { and are of professional } \\
\text { quality. }\end{array}$ & \begin{tabular}{|l|} 
Clear figures with \\
good formatting. \\
Most aid the report \\
presentation and are \\
of professional quality.
\end{tabular} & $\begin{array}{l}\text { Clear figures with } \\
\text { good formatting. } \\
\text { Some aid in the } \\
\text { report presentation; } \\
\text { professional quality } \\
\text { could be improved. }\end{array}$ & $\begin{array}{l}\text { Unclear figures. } \\
\text { Formatting detracts } \\
\text { from presentation. }\end{array}$ \\
\hline 7.1 & \begin{tabular}{l|} 
Develop and deliver clear, \\
key concepts using \\
methods appropriate for \\
the intended audience - \\
Literacy
\end{tabular} & $\begin{array}{l}\text { Flawless English } \\
\text { with no punctuation } \\
\text { errors. }\end{array}$ & $\begin{array}{l}\text { A few flaws in English } \\
\text { grammar or spelling. } \\
\text { Punctuation errors are } \\
\text { infrequent. }\end{array}$ & $\begin{array}{l}\text { Some flaws in } \\
\text { English grammar, } \\
\text { spelling and } \\
\text { punctuation, but } \\
\text { do not severely } \\
\text { inhibit reading of } \\
\text { report. }\end{array}$ & $\begin{array}{l}\text { Very seriously flawed } \\
\text { English spelling, } \\
\text { grammar and } \\
\text { punctuation. Report } \\
\text { is difficult to read. }\end{array}$ \\
\hline 11 & \multicolumn{5}{|c|}{$\begin{array}{l}\text { Economics and Project Management: An ability to appropriately incorporate economics and business practices including } \\
\text { project, risk, and change management into the practice of engineering and to understand their limitations. }\end{array}$} \\
\hline 11.1 & $\begin{array}{l}\text { Apply project management } \\
\text { techniques and manage } \\
\text { resources within identified } \\
\text { constraints - Method of } \\
\text { approach suitable for a } \\
\text { proposal. }\end{array}$ & $\begin{array}{l}\text { Construct and critically } \\
\text { discuss the project } \\
\text { timeline }\end{array}$ & $\begin{array}{l}\text { Construct and briefly } \\
\text { comment on the project } \\
\text { timeline }\end{array}$ & $\begin{array}{l}\text { Construct a project } \\
\text { timeline }\end{array}$ & Poor project timeline \\
\hline 11.1 & $\begin{array}{l}\text { Apply project management } \\
\text { techniques and manage } \\
\text { resources within identified } \\
\text { constraints - Estimated cost } \\
\text { of completing the design; } \\
\text { appropriate for a proposal. }\end{array}$ & $\begin{array}{l}\text { Excellent cost analysis } \\
\text { supported with } \\
\text { discussion. }\end{array}$ & $\begin{array}{l}\text { Very good cost } \\
\text { analysis supported } \\
\text { with discussion. }\end{array}$ & Good cost analysis. & Poor cost analysis. \\
\hline & & & & & Total out of 48 \\
\hline
\end{tabular}

